\title{
Cardiomyopathy and Death Following Chikungunya Infection: An Increasingly Common Outcome
}

\author{
Elizabeth M. Traverse ${ }^{1}$, Hannah K. Hopkins ${ }^{1}$, Vedana Vaidhyanathan ${ }^{2}$ and Kelli L. Barr ${ }^{1, *}$ D \\ 1 Center for Global Health and Infectious Disease Research, University of South Florida, Tampa, FL 33612, USA; \\ emtraverse@usf.edu (E.M.T.); Hannahhopkins@usf.edu (H.K.H.) \\ 2 Central Libraries Research Engagements, Baylor University, Waco, TX 76706, USA; \\ Vedana_vaidhyanathan@baylor.edu \\ * Correspondence: barrk@usf.edu; Tel.: +1-(813)-974-4480
}

\section{check for} updates

Citation: Traverse, E.M.; Hopkins, H.K.; Vaidhyanathan, V.; Barr, K.L. Cardiomyopathy and Death Following Chikungunya Infection: An Increasingly Common Outcome Trop. Med. Infect. Dis. 2021, 6, 108. https://doi.org/10.3390/ tropicalmed6030108

\section{Academic Editors:}

Constantinos Tsioutis and Spyridon Karageorgos

Received: 29 April 2021

Accepted: 18 June 2021

Published: 22 June 2021

Publisher's Note: MDPI stays neutral with regard to jurisdictional claims in published maps and institutional affiliations.

Copyright: (c) 2021 by the authors. Licensee MDPI, Basel, Switzerland. This article is an open access article distributed under the terms and conditions of the Creative Commons Attribution (CC BY) license (https:// creativecommons.org/licenses/by/ $4.0 /)$.
Abstract: Chikungunya virus (CHIKV) is vectored by Aedes aegypti and Aedes albopictus mosquitoes and is found throughout tropical and sub-tropical regions. While most infections cause mild symptoms such as fever and arthralgia, there have been cases in which cardiac involvement has been reported. In adults, case reports include symptoms ranging from tachycardia and arrythmia, to myocarditis and cardiac arrest. In children, case reports describe symptoms such as arrythmia, myocarditis, and heart failure. Case reports of perinatal and neonatal CHIKV infections have also described cardiovascular compromise, including myocardial hypertrophy, ventricular dysfunction, myocarditis, and death. Myocarditis refers to inflammation of the heart tissue, which can be caused by viral infection, thus becoming viral myocarditis. Since viral myocarditis is linked as a causative factor of other cardiomyopathies, including dilated cardiomyopathy, in which the heart muscle weakens and fails to pump blood properly, the connection between CHIKV and the heart is concerning. We searched Pubmed, Embase, LILACS, and Google Scholar to identify case reports of CHIKV infections where cardiac symptoms were reported. We utilized NCBI Virus and NCBI Nucleotide to explore the lineage/evolution of strains associated with these outbreaks. Statistical analysis was performed to identify which clinical features were associated with death. Phylogenetic analysis determined that CHIKV infections with cardiac symptoms are associated with the Asian, the East Central South African, and the Indian Ocean lineages. Of patients admitted to hospital, death rates ranged from 26-48\%. Myocarditis, hypertension, pre-existing conditions, and the development of heart failure were significantly correlated with death. As such, clinicians should be aware in their treatment and follow-up of patients.

Keywords: CHIKV; chikungunya; myocarditis; cardiomyopathy; cardiovascular

\section{Introduction}

Chikungunya (CHIKV) is a positive sense RNA alphavirus generally vectored by Aedes aegypti and Aedes albopictus mosquitoes [1,2]. On the approximately $12 \mathrm{~kb}$ RNA genome of $\mathrm{CHIKV}$, there are two open reading frames in which the non-structural proteins nsP1, nsP2 (helicase), nsP3, and nsP4 (polymerase) or the structural proteins E1, E2, and E3 envelope proteins, capsid, and 6k are coded for, respectively [2,3]. After human infection via an infected mosquito's bite, CHIKV virions can target a vast array of cell types, including endothelial, epithelial, fibroblastic, and even muscle satellite cells [3-5]. Within vertebrate cells, the full virion replication cycle is typically complete in $8 \mathrm{~h}$, and a host will generally begin to show symptoms between four and seven days following the initial mosquito bite [3,4].

Originally isolated in Tanzania in 1952, it is suspected that outbreaks of CHIKV may have occurred as early as 1823 in Zanzibar, and kept mostly to Africa and Asia prior to 2007 [1,6]. Phylogenetic analysis breaks CHIKV down into three major branches, the West African lineage, the East, Central, and South African lineage (ECSA), and the Asian 
lineage $[1,7,8]$. Between the 1960s and 1980s, several outbreaks caused by these strains occurred across tropical and subtropical regions of Africa and Asia, until an apparent lapse in activity which was resumed in 2004 when an additional phylogenetic group derived from the ECSA strain was identified, the Indian Ocean sub-lineage (IOL) $[1,7,9]$. Following the CHIKV reemergence in 2004-2005, several new outbreaks began, specifically on La Reunion, which introduced a new strain variant with the E1 A226V mutant $[1,2,10]$. This mutation is thought to increase transmissibility and infection in Ae. albopictus mosquitos [10]. From 2005 and onward, there have been several outbreaks across Africa and Asia, spreading to Italy, South and Central America, and the Caribbean [1]. While many of these outbreaks in the Americas are of the Asian lineage, which have begun to accrue their own mutations and possibly a sub-lineage, ECSA strains are also present, especially in Brazil [8,11,12]. Rezza et al. shows a comprehensive diagram of strains and their spread across the world [13]. Corresponding with the La Reunion (2005-2006) and later outbreaks was an increase in reports of differing and serious clinical presentations of CHIKV infection, including ocular, renal, respiratory, neurological, and cardiovascular complications $[1,2,7,10,14,15]$.

When a human is infected with CHIKV, it usually results in fever, muscle pain, polyarthralgia, and occasionally a rash [3,7]. Recent reports have described cardiac involvement during infections across the world (Table 1 and Figure 1). These cases occur in all age groups, from neonates to the elderly, and generally those who are older and with cardiac related preexisting conditions seem to be at higher risk [16,17]. Many of the cardiac symptoms include arrythmias, abnormal echocardiograms and electrocardiograms, myocarditis and death [15]. Further, the finding of viral myocarditis is concerning due to its connection with other cardiomyopathies such as dilated cardiomyopathy, which can also result in death $[18,19]$. While most CHIKV infections result in mild symptoms, myocarditis does not always present overtly, which could lead to a future high burden on healthcare systems where outbreaks have occurred [18]; a number of these countries have underdeveloped infrastructure; thus, this burden could be overwhelming [20,21]. Since there is no distinct course of action for CHIKV infection, nor a vaccine, CHIKV infection should be concerning to clinicians [22].

\section{Global Locations of Chikungunya Infection with Cardiac Involvemnet}

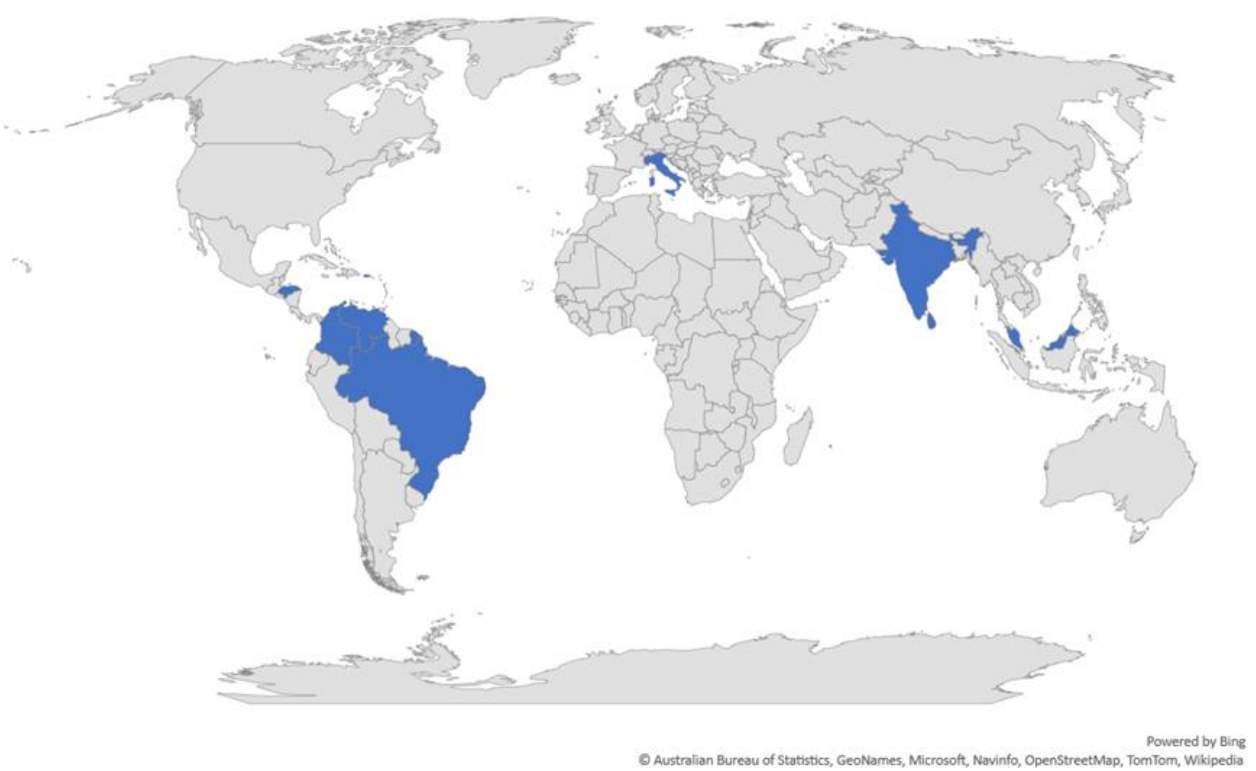

Figure 1. Countries in which a CHIKV infection involved altered cardiac status spanning 1970-2020. 


\section{Materials and Methods}

Case study literature included in this review was sourced from the following databases: Pubmed, Embase, LILACS, and Google Scholar. The following search terms were used: "('CHIKV' / exp OR CHIKV) AND ('heart disease' / exp OR 'heart disease')”, “CHIKV and heart", "CHIKV and myocarditis", "CHIKV virus infection and cardiovascular involvement". Some articles were found via direct search based on works cited by other articles. Inclusion criteria for case studies included confirmed CHIKV infection and altered cardiac status, including reported tachycardia, bradycardia, arrythmia, myocarditis, myocardial infarct, abnormal electrocardiogram, abnormal echocardiogram, heart failure, cardiac arrest, and/or cardiorespiratory failure. Case reports of individuals that were pregnant but not in the peri-partum period, and those with malaria or autoimmune conditions (i.e., lupus, HIV) were excluded from the analysis. Statistical tests included ANOVA, Student's $t$-test, and Pearson's correlation tests.

Phylogenetic trees were created using the data and phylogenetic analysis software on NCBI Virus (https:/ / www.ncbi.nlm.nih.gov/labs/virus/vssi/\#/ (accessed on 21 June 2021)) [23]. Data points were selected based on year and location in which the samples were collected, exclusively from Homo sapiens samples. Sequences used were at least 10,000 nucleotides long, in an effort to get as close to the full sequence as possible. Specifically, data points for Figure 2 were selected based on the collection date corresponding to year and location in which a CHIKV outbreak had at least one reported case of altered cardiac status (see Table 1). For Figure 3, the same data points as Figure 2 (highlighted) were expanded upon to include data from all outbreaks through 2005 that fell under the criteria described above. For both trees, only one sample from each year and location combination was included.

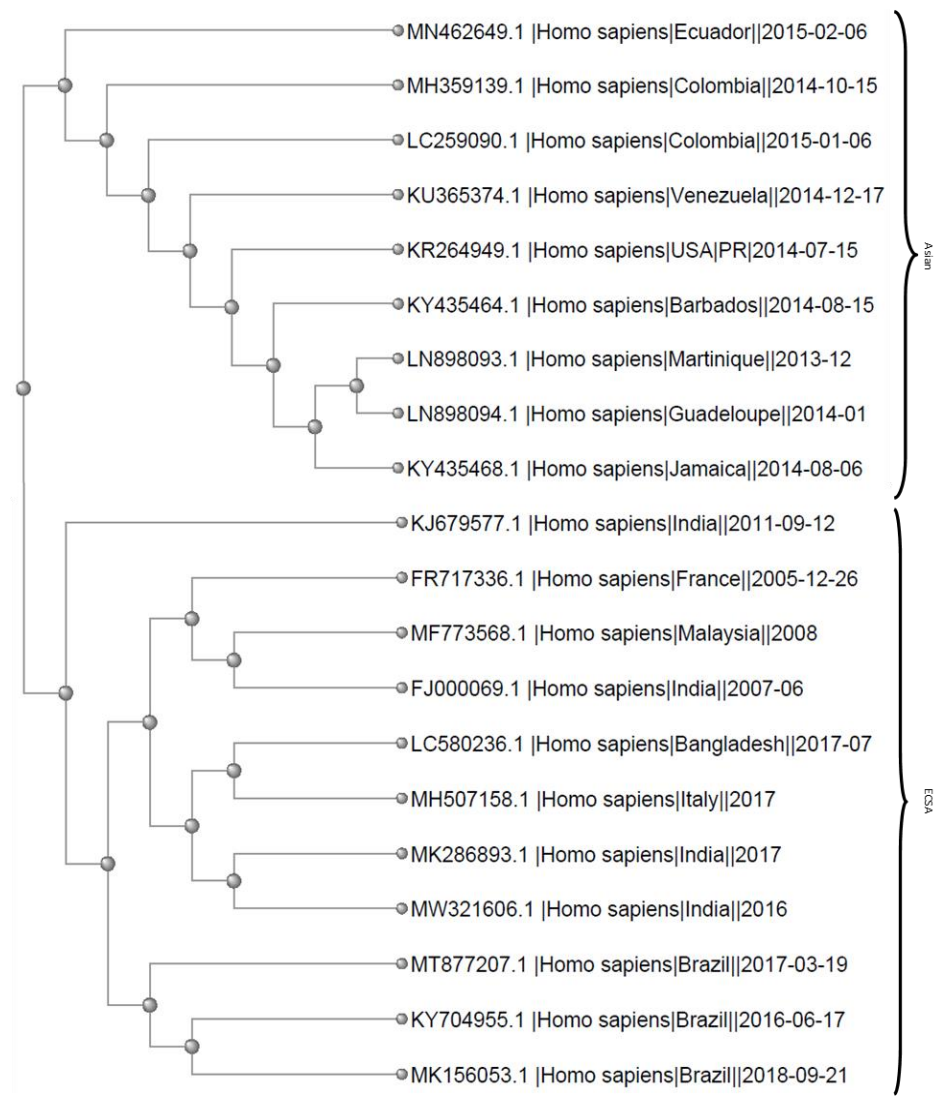

Figure 2. Phylogenetic tree showing strains of CHIKV taken from Homo sapiens samples that were obtained at the same location during the outbreaks in which altered cardiac status was reported. The strains and tree were developed using the NCBI viruses software [23]. 


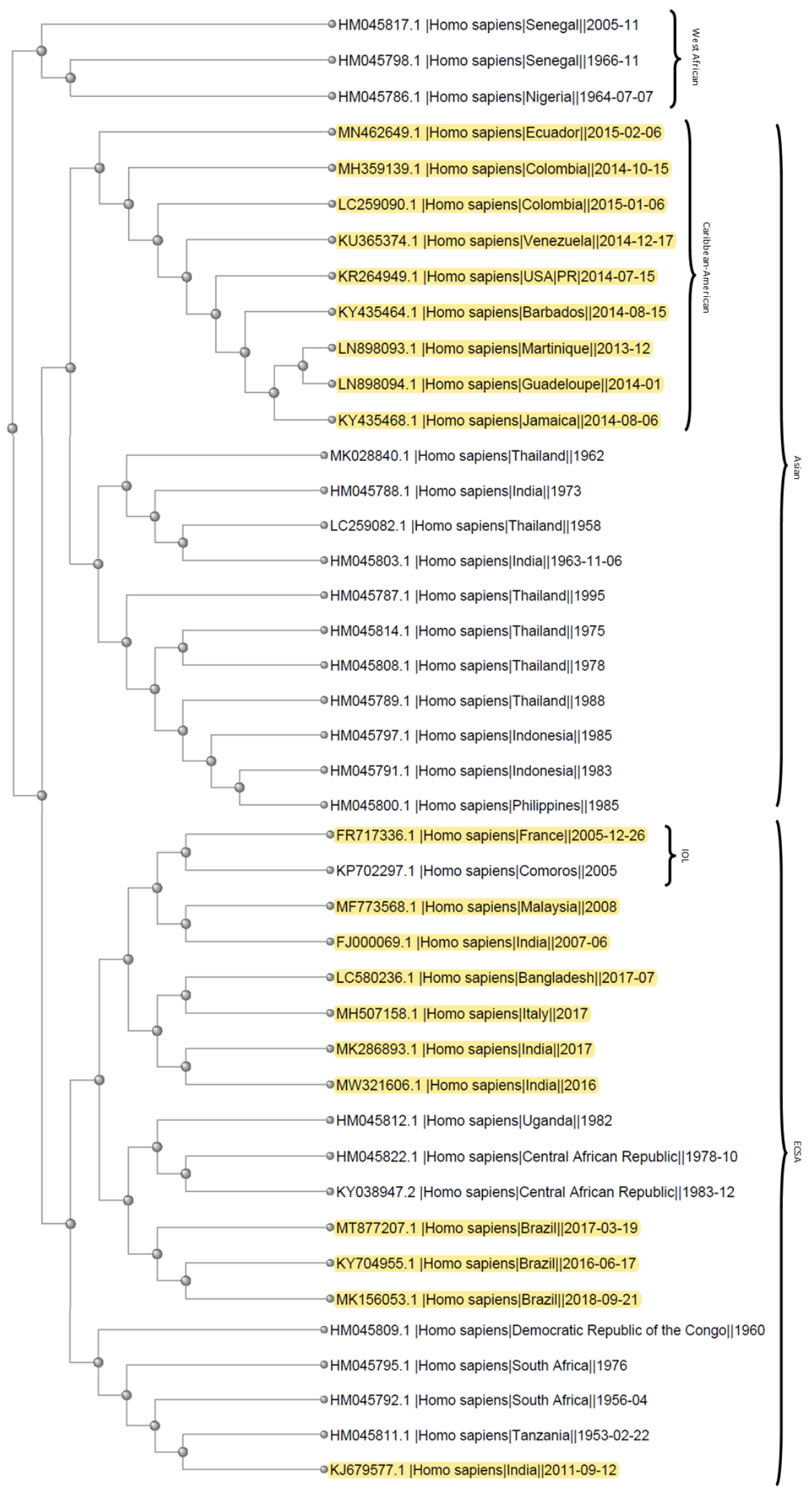

Figure 3. Phylogenetic tree listing several outbreaks from 1953 through 2005, with the addition of the strains in Figure 2. These strains and the tree were developed using the NCBI Viruses database [23]. Based on the strain data from NCBI, the three main branches are labeled to indicate West African, ECSA, or Asian lineages. Additionally, the sub-lineages for IOL and Caribbean-American are labeled. The strains from Figure 2 are highlighted. 


\section{Results}

\subsection{Locations of CHIKV Infections with Cardiac Symptoms}

CHIKV infections with cardiac symptoms were reported across the globe (Figure 1). The earliest of these reports occurred in Sri Lanka and India in the 1970s, followed by a gap of nearly 30 years without report, which likely coincided with a reduction in CHIKV outbreaks [1,24-26] (Table 1). Following the Reunion Island outbreak in 2004-2005, an increase in reporting of cardiac related incidents during CHIKV infection occurred, which may indicate newer strains have a higher likelihood of affecting the heart, or a lack of reporting in previous outbreaks $[1,11,27]$ (Table 1$)$.

Table 1. Location and year of case studies in which altered cardiac status was reported. Strain information was taken from these case studies when available or taken from other sources reporting outbreaks in the same locations in the same year.

\begin{tabular}{ccc}
\hline Location & Year & Lineage \\
\hline Sri Lanka [24,25] & 1972 & Asian [28] \\
India [26] & 1978 & Asian [28] \\
Reunion Island [29-34] & 2005 & IOL [35] \\
Kerala, India [36] & 2007 & IOL [36] \\
Malaysia [37] & 2008 & ECSA [37] \\
Aaryad, Kerala, India [38] & 2009 & IOL [39,40] \\
Malaysia [41] & 2010 & ECSA [41] \\
India [42] & 2011 & ECSA [39] \\
Guadeloupe and Martinique [43] & $2013-2014$ & Asian [27] \\
Caribbean [44] & $2013-2014$ & Asian [27] \\
Jamaica [45] & 2014 & Asian [27] \\
Venezuela [46-49] & 2014 & Asian [49] \\
Barbados [50] & 2014 & Asian [50] \\
French West Indies [51] & 2014 & Asian [51] \\
Tahiti, French Polynesia [52] & 2014 & Asian [52] \\
Puerto Rico [53-55] & 2014 & Asian [56] \\
San Salvador/El Salvador [57] & 2014 & Asian [57] \\
Willemstad, Curacao [58] & Asian [59] \\
French Guiana [14] & 2014 & Asian [11] \\
Sucre, Colombia [60] & $2014-2015$ & Asian [11] \\
Columbia [61] & $2014-2015$ & Asian [11] \\
Machala, Ecuador [62] & 2015 & Asian [62] \\
North India [63] & 2015 & Asian or ECSA [64] \\
Paraiba, Brazil [65] & 2016 & Asian or ECSA [12] \\
Ceara, Brazil [66] & 2016 & Asian or ECSA [12] \\
Brazil [21,67-69] & Asian or ECSA [12] \\
Dhaka, Bangladesh [70] & IOL [70] \\
Italy [71] & IOL [71] \\
India [72] & $2016-2017$ & Asian [73] \\
Columbia [74] & 2017 & Asian or ECSA [12] \\
Brazil [75] & 2017 & \\
\hline
\end{tabular}

\subsection{Phylogenetics}

Phylogenetic trees were designed using the NCBI Viruses software [23]. Analysis of CHIKV taken from human patients that correlate with outbreaks in which altered cardiac status was reported produced two major branches, representing the Asian and ESCA strains which have spread throughout the world in a documented manner (Figure 2) [13]. There were no reports of the West African lineage causing cardiac related symptoms.

Analysis of CHIKV taken from human patients that correlate with outbreaks in which altered cardiac status and 22 additional sequences from other CHIKV outbreaks (19532005) was performed in order to provide additional genetic material to determine if the bifurcated tree in Figure 2 was significant [23]. The analysis shows three major branches, 
representing the West African, ECSA, and Asian lineages (Figure 3). Again, no reports of cardiac involvement were associated with the West African lineage.

\subsection{CHIKV Causes Cardiac Symptoms and Death}

In non-pregnant adults (those over 18 years), there was a range of altered cardiac status. Many sources reported arrythmia in general, as well as palpitations $[15,46,53,76,77]$ (Tables 2 and 3). Additional cardiac alterations included myocardial infarct, heart failure, cardiac arrest, and myocarditis [14,26,29,30,41,43,44,53,61,67,74] (Tables 2 and 3). In children (ages 1 year to 18 years), the symptoms were similar to that in adults with tachycardia, bradycardia, hypertensive shock, myocarditis, cardiorespiratory failure, and death being reported $[2,34,38,50,52,66,72]$ (Tables 2 and 3). Reports of altered cardiac symptoms in infants include tachycardia, heart murmur, hypertension, ventricular dysfunction, pericardial effusion, myocarditis, and death [32,33,42,45,51,54,57,58,60,63,69,78] (Tables 2 and 3). Pregnant mothers were reported to experience gestational hypertension, cardiorespiratory failure, and death $[62,69]$ (Tables 2 and 3).

There are a number of cases in which the CHIKV infection may have aggravated a pre-existing heart condition, including hypertension, ischemic heart disease, cardiac compromise, and heart failure [37,41,44,55,61,70,71,74,79,80] (Tables 2 and 3). Additionally, those who are elderly, especially if they have cardiac alterations, were found to be at higher risk of death [81] (Tables 2 and 3). However, there are also reports of individuals with no pre-existing conditions dying of acute cardiac arrest, cardiorespiratory failure, and cardiac decompensation, including infants and children following CHIKV infection $[57,60,66,69]$ (Tables 2 and 3).

In three studies, patients who developed myocarditis, with or without pre-existing conditions, were at risk of death $[44,52,57]$ (Tables 2 and 3). Five studies reported that when patients were admitted to hospitals, the mortality rate for CHIKV positive patients with severe conditions (including cardiac compromise) ranged from $26 \%$ to $48 \%[30,43,44,49,82]$ (Tables 2 and 3). In order to explore specific clinical features and their correlation with death, studies were divided into single patient case reports and clinical studies with multiple patients. It is of note that all of the cases found were of the Asian and ECSA lineages and sub-lineages. Data showing altered cardiac status was not found in the West African strain.

Table 2. Cardiac complications from individual patients infected with CHIKV. Lineage was determined from the data in the case studies when available. When the lineage was not reported, the year and location was matched to isolates in NCBI Nucleotide with Table 1 to deduce the lineage. NR = not reported, CABG = coronary artery bypass graft.

\begin{tabular}{cclll}
\hline Patient & Sex/Age & Pre-Existing Conditions & Symptoms & Lineage \\
\hline 1 & F/44 & $\begin{array}{l}\text { Tachycardia, ventricular abnormalities, gallop } \\
\text { rhythm, cardiomegaly, abnormal } \\
\text { electrocardiogram, later developed congestive } \\
\text { cardiomyopathy [24] }\end{array}$ & Asian \\
\hline 2 & $\mathrm{M} / 46$ & Fever three months prior & Atrial fibrillation and cardiomegaly [24] & Asian \\
\hline 3 & $\mathrm{~F} / 21$ & $\begin{array}{l}\text { Myopericarditis, pericardial effusion, } \\
\text { abnormal echocardiogram, abnormal } \\
\text { electrocardiogram [83] }\end{array}$ & $\begin{array}{l}\text { Myocarditis, abnormal electrocardiogram, } \\
\text { abnormal echocardiogram, congestive cardiac } \\
\text { failure [38] }\end{array}$ \\
\hline 5 & $\mathrm{M} / 5.5$ & Hypertension, alcoholic \\
cardiomyopathy & Acute decompensated heart failure [75] & IOL \\
\hline
\end{tabular}


Table 2. Cont.

\begin{tabular}{|c|c|c|c|c|}
\hline Patient & Sex/Age & Pre-Existing Conditions & Symptoms & Lineage \\
\hline 6 & $\mathrm{M} / 28$ & & $\begin{array}{l}\text { Tachycardia, hypotension, abnormal } \\
\text { electrocardiogram, abnormal echocardiogram, } \\
\text { pericardial effusion, altered LV ejection } \\
\text { fraction, LV hypercontractility, myocarditis, } \\
\text { DENV coinfection [67] }\end{array}$ & ECSA or Asian \\
\hline 7 & $\mathrm{M} / 77$ & $\begin{array}{l}\text { Hypertension, ischemic } \\
\text { heart disease, CABG }\end{array}$ & $\begin{array}{l}\text { Acute cardiac arrest, death, abnormal } \\
\text { electrocardiogram, abnormal echocardiogram, } \\
\text { dilated left cardiomyopathy [71] }\end{array}$ & IOL \\
\hline 8 & $\mathrm{M} / 0$ & & $\begin{array}{l}\text { Tachycardia, bradycardia, pulmonary } \\
\text { hemorrhage, death [69] }\end{array}$ & ECSA or Asian \\
\hline 9 & NR & & $\begin{array}{l}\text { Fetal heart rhythm abnormalities, fetal } \\
\text { distress, intracerebral hemorrhage, death [58] }\end{array}$ & Asian \\
\hline 10 & NR & & $\begin{array}{l}\text { Fetal heart rate abnormalities, fetal distress, } \\
\text { skin rash went away [58] }\end{array}$ & Asian \\
\hline 11 & $\mathrm{M} / 12$ & & $\begin{array}{l}\text { Hypotensive shock, hemodynamic instability, } \\
\text { abnormal echocardiogram, LV hypokinesia, } \\
\text { LV dysfunction, hypotension, } \\
\text { myocarditis [72] }\end{array}$ & ECSA \\
\hline 12 & $\mathrm{M} / 5$ & & Cardiorespiratory arrest, death [66] & ECSA or Asian \\
\hline 13 & $\mathrm{~F} / 51$ & & $\begin{array}{l}\text { Respiratory difficulties, cardiorespiratory } \\
\text { arrest, death [66] }\end{array}$ & ECSA or Asian \\
\hline 14 & $\mathrm{~F} / 0.25$ & & Tachycardia, abnormal electrocardiogram [78] & ECSA or Asian \\
\hline 15 & $\mathrm{~F} / 0$ & & Fetal pericardial effusion, cardiomegaly [42] & ECSA or Asian \\
\hline 16 & $\mathrm{M} / 75$ & & $\begin{array}{l}\text { Tachycardia, multi-organ failure, } \\
\text { hemodynamic instability, atrial fibrillation, } \\
\text { cardiorespiratory arrest, death [49] }\end{array}$ & Asian \\
\hline 17 & $\mathrm{M} / 65$ & Hypertension & $\begin{array}{l}\text { Tachycardia, hypotensive, cardiac arrest, } \\
\text { death [49] }\end{array}$ & Asian \\
\hline 18 & $\mathrm{~F} / 32$ & & $\begin{array}{l}\text { Hypotension, tachycardia, hemodynamic } \\
\text { instability, abnormal echocardiogram [49] }\end{array}$ & Asian \\
\hline 19 & $\mathrm{~F} / 10$ & $\begin{array}{l}\text { SCN5A mutation, } \\
\text { bradycardia }\end{array}$ & $\begin{array}{l}\text { Bradycardia, cardiac sinus node dysfunction, } \\
\text { needed pacemaker [84] }\end{array}$ & IOL \\
\hline 20 & $\mathrm{~F} / 66$ & & $\begin{array}{l}\text { Tachycardia, became hypertensive, cardiac } \\
\text { decompensation, cardiac arrhythmia, } \\
\text { death [41] }\end{array}$ & ECSA \\
\hline 21 & $\mathrm{~F} / 0$ & & $\begin{array}{l}\text { Bradycardia, hypotensive, possible septic } \\
\text { shock, death [45] }\end{array}$ & Asian \\
\hline 22 & $\mathrm{M} / 87$ & $\begin{array}{l}\text { DENV, leptospirosis, } \\
\text { chronic heart failure }\end{array}$ & Cardiac deterioration, death [74] & Asian \\
\hline 23 & $\mathrm{~F} / 53$ & $\begin{array}{l}\text { Hypertension, } \\
\text { cardiac failure }\end{array}$ & $\begin{array}{l}\text { Cardiomegaly, abnormal echocardiogram, } \\
\text { death [37] }\end{array}$ & ECSA \\
\hline
\end{tabular}


Table 3. Cardiac complications from literature that complied multiple patients. Lineage was obtained from the data when available. When unavailable, the year and location was matched to isolates in NCBI Nucleotide with Table 1 to deduce the lineage.

\begin{tabular}{|c|c|c|c|c|c|c|}
\hline Total Patients & \# Male & \# Female & Age Range & $\begin{array}{l}\text { Pre-Existing } \\
\text { Conditions }\end{array}$ & Symptoms & Lineage \\
\hline 42 & 20 & 22 & $\begin{array}{l}\text { Median } 60,17 \text { over } 65 \\
16 \text { under } 40\end{array}$ & & $\begin{array}{l}\text { All patients showed palpitations, } \\
\text { abnormal electrocardiogram in } 71.4 \% \text {, } \\
\text { myocarditis suspected in } 100 \%[85]\end{array}$ & Asian \\
\hline 16 & 14 & 2 & $\begin{array}{l}\text { Median } 9.5 \text { days, up } \\
\text { to } 3 \text { months }\end{array}$ & & $\begin{array}{l}\text { Cardiovascular involvement including } \\
\text { high pulmonary pressures in } 4 \text {, } \\
\text { myocarditis in } 1 \text {, one death due to } \\
\text { multi-organ failure [50] }\end{array}$ & Asian \\
\hline $\begin{array}{l}399 \text { confirmed, } \\
291 \text { probables }\end{array}$ & 395 & 295 & $\begin{array}{l}\text { Median } 38 \text { years, } \\
\text { range } 21-96\end{array}$ & $\begin{array}{l}8.9 \% \text { with } \\
\text { hypertension, } 1.5 \% \\
\text { with ischemic heart } \\
\text { disease }\end{array}$ & Hypotension in 5 , mortality rate of $0.5 \%$ [70] & IOL \\
\hline 21 & 10 & 11 & Median 3 months & & At least 1 with myocarditis [54] & Asian \\
\hline 64 & 37 & 27 & $\begin{array}{l}\text { Median 62, range } \\
\quad 49-71\end{array}$ & $\begin{array}{l}\text { Hypertension in } 37, \\
\text { chronic heart failure } \\
\text { in } 12\end{array}$ & $\begin{array}{l}2 \text { had myocarditis, evidence of } \\
\text { exacerbation of preexisting conditions, } \\
\text { both myocarditis patients died (they did } \\
\text { not have preexisting conditions, } 11 \text { and } \\
56 / F) \text { [52] }\end{array}$ & Asian \\
\hline $\begin{array}{l}203 \text { suspected, } \\
69 \text { confirmed }\end{array}$ & & & $\begin{array}{l}\text { Children less than } \\
15 \text { years }\end{array}$ & & $\begin{array}{l}\text { DENV coinfection, myocarditis, and } \\
\text { bradycardia in one [50] }\end{array}$ & Asian \\
\hline 287 & 117 & 170 & $59+/-8$ & & $\begin{array}{l}91 \text { had palpitations, } 45 \% \text { had arrythmia } \\
\text { (33\% bradyarrhythmia), } 19 \text { cases of } \\
\text { tachyarrhythmia, tachycardia, } 3 \text { cases of } \\
\text { sudden death. Possible myocarditis }[48]\end{array}$ & Asian \\
\hline 180 & 167 & 13 & $\begin{array}{l}68.8+/-16.2,54.8 \\
+/-16.5\end{array}$ & $\begin{array}{l}\text { Hypertension in } \\
\text { 118, coronary heart } \\
\text { disease in 32, } \\
\text { congestive heart } \\
\text { failure in } 13\end{array}$ & $\begin{array}{l}4 \text { patients experienced exacerbation of } \\
\text { congestive heart failure [86] }\end{array}$ & Asian \\
\hline 257 & 133 & 124 & $63+/-9$ & Hypertension in 63 & $\begin{array}{l}\text { Arterial hypotension in } 25,51 \% \text { had } \\
\text { arrhythmias, } 33 \% \text { had bradyarrhythmia's } \\
{[47]}\end{array}$ & Asian \\
\hline 43 & 18 & 25 & $\begin{array}{l}\text { mean } 62.5 \text {, range } \\
24-88\end{array}$ & $\begin{array}{l}84 \% \text { had } \\
\text { comorbidities }\end{array}$ & $\begin{array}{l}\text { Chronic cardiac failure in } 7 \text {, cardiac } \\
\text { arrest in } 4 \text {, related to comorbidities, } 49 \% \\
\text { mortality rate, exacerbation of previous } \\
\text { conditions [29] }\end{array}$ & IOL \\
\hline 209 & 65 & 144 & $\begin{array}{c}99 \text { aged } 20-40,77 \\
\text { aged } 40-60,17 \text { aged } \\
60-80,13 \text { aged } 10-20 \\
3 \text { aged } 80+\end{array}$ & & Myocarditis in 1 [36] & IOL \\
\hline 610 & 271 & 339 & $\begin{array}{l}\text { median } 70, \text { range } \\
15-95\end{array}$ & $\begin{array}{l}546 \text { with } \\
\text { comorbidity }\end{array}$ & $\begin{array}{l}226 \text { with cardiac abnormality, } 110 \text { of } \\
\text { these had underlying cardiac condition, } \\
137 \text { had hypertension; } 84 \text { cases had heart } \\
\text { failure, } 29 \text { of which had underlying } \\
\text { cardiomyopathy, } 10 \text { with coronary artery } \\
\text { disease, } 6 \text { with valvular disease, } 4 \text { with } \\
\text { history of myocardial infarction, and } 1 \\
\text { with arrhythmias; } 35 \text { cases of } \\
\text { myocarditis, } 4 \text { cases of acute myocardial } \\
\text { infarction [31] }\end{array}$ & IOL \\
\hline 33 & & & adults & $\begin{array}{c}18 \% \text { had } \\
\text { exacerbations of } \\
\text { previous conditions }\end{array}$ & 1 with myocarditis [30] & IOL \\
\hline 38 & & & $\begin{array}{l}\text { neonates (average } \\
\text { symptoms day } 4 \text { ) }\end{array}$ & & $\begin{array}{l}\text { Abnormal echocardiograms in } 16, \\
\text { showing hypertrophy in } 5 \text {, ventricular } \\
\text { dysfunction in } 2, \text { pericarditis in } 2, \\
\text { coronary artery dilation in } 6[32]\end{array}$ & IOL \\
\hline 86 & 50 & 36 & $\begin{array}{l}\text { median } 3.5 \text {, range } \\
3 \text { weeks-17 years }\end{array}$ & & $\begin{array}{l}7 \text { total with cardiac symptoms, } 2 \text { with } \\
\text { heart rhythm disturbances [33] }\end{array}$ & IOL \\
\hline 9 & & & children & & $\begin{array}{l}5 \text { with cardiac complications including } \\
\text { myocarditis and hemodynamic } \\
\text { disorders [34] }\end{array}$ & IOL \\
\hline 23 & 19 & 4 & $\begin{array}{l}1 \text { aged } 31-40,1 \text { aged } \\
41-50,4 \text { aged } 51-60,5 \\
\text { aged } 61-70,9 \text { aged } \\
71-80,3 \text { aged } 81-90\end{array}$ & & $\begin{array}{l}3 \text { patients with cardiac involvement, } \\
\text { cardiogenic shock causing death in } 1 \text { [82] }\end{array}$ & IOL \\
\hline
\end{tabular}




\subsection{Clinical Features of Single Patient Case Reports}

Of 23 unique case reports, 11 were male, 10 were female and two were not reported (Tables 2 and 4). Seven cases had documented pre-existing conditions (Tables 2 and 4). Tachycardia was documented in nine cases, arrythmia in 12 but no cases reported palpitations (Tables 2 and 4). Six patients had abnormal electrocardiograms and seven had abnormal echocardiograms (Tables 2 and 4). Four patients had clinical hypertension while five developed hypotension (Tables 2 and 4). Cardiomegaly was observed in four cases and heart failure reported in 11 cases (Tables 2 and 4). Myocarditis was reported in four cases (Tables 2 and 4 ).

Death caused directly by CHIKV infection is not commonly reported; however, there are reports of excess deaths in countries in which a CHIKV epidemics have occurred $[20,21,55,87,88]$ (Tables 2 and 4). In regard to CHIKV infections with altered cardiac status, 11 deaths were reported out of 23 individual case reports (48\%) (Table 4). There was no correlation between the incidence of pre-existing conditions, hypertension, hypotension, abnormal electrocardiogram/echocardiogram, palpitations, arrythmias, tachycardia, A226V mutation, sex, or cardiomegaly with death (Table 4). However, patients infected with the Asian lineage and those with heart failure or myocarditis were significantly correlated with death (Table 4$)(p=0.0224, p=0.0213, p=0.036)$.

Table 4. Incidence of specific features of CHIKV-infected patients with cardiac symptoms. Pearson's Correlation Coefficients were obtained to determine if there were any specific features associated with death.

\begin{tabular}{cccc}
\hline Feature & $\mathbf{N ~ ( \% )}$ & Correlation Coefficient & $p$ Value \\
\hline Male & $11(48 \%)$ & 0.1455 & 0.5293 \\
Female & $10(43 \%)$ & -0.1455 & 0.5293 \\
Preexisting Condition & $7(30 \%)$ & 0.1234 & 0.5749 \\
A226V mutation & $4(17 \%)$ & -0.2097 & 0.3370 \\
Asian Lineage & $7(41 \%)$ & 0.5494 & 0.0224 \\
Tachycardia & $9(39 \%)$ & -0.0542 & 0.8057 \\
Arrythmia & $12(52 \%)$ & 0.0454 & 0.8368 \\
Palpitations & 0 & NA & NA \\
Hypertension & $4(17 \%)$ & 0.2496 & 0.2507 \\
Hypotension & $5(22 \%)$ & -0.0825 & 0.7080 \\
Myocarditis & $4(17 \%)$ & -0.4393 & 0.0360 \\
Cardiomegaly & $4(17 \%)$ & -0.2097 & 0.3370 \\
Heart Failure & $11(48 \%)$ & 0.4773 & 0.0213 \\
Abnormal electrocardiogram & $6(100 \%)$ & 0 & 1 \\
Abnormal echocardiogram & $7(100 \%)$ & 0 & 1 \\
Death & $11(48 \%)$ & NA & NA \\
\hline
\end{tabular}

\subsection{Clinical Features of Patients from Clinical Studies with Multiple Patients}

We identified 17 studies that described 2880 patients in clinical studies combining data from multiple patients. When complied, the data show that men and women were equally represented for having cardiac symptoms ( $p=0.2379, p=0.0623$, respectively) (Table 5). Nor was there a specific CHIKV lineage associated with death $(p=0.2534)$ (Table 5$)$. The most commonly reported clinical features were having a pre-existing condition and hypertension (Table 5). Electrocardiograms and echocardiograms were performed in a fraction of patients. When reported, $95 \%$ of CHIKV-infected patients had abnormal electrocardiogram and $82 \%$ had abnormal echocardiograms (Table 5); 142 (5\%) of 2880 patients died (Table 5). Here death was significantly correlated with having a pre-existing condition $(p=0.0001)$, having hypertension $(p=0.0001)$, and having heart failure $(p=0.0001)$ (Table 5). 
Table 5. Incidence of specific features of CHIKV-infected patients from clinical studies with cardiac symptoms. Pearson's Correlation Coefficients were obtained to determine if there were any specific features associated with death.

\begin{tabular}{cccc}
\hline Feature & $\mathbf{N}(\mathbf{\%})$ & Correlation Coefficient & $p$ Value \\
\hline Male & $1316(52 \%)$ & 0.3522 & 0.2379 \\
Female & $1212(48 \%)$ & 0.5303 & 0.0623 \\
Preexisting Condition & $935(32 \%)$ & 0.8893 & 0.0001 \\
A226V mutation & $9(53 \%)$ & 0.2932 & 0.2534 \\
Asian & $8(47 \%)$ & -0.2932 & 0.2534 \\
IOL & $9(53 \%)$ & 0.2932 & 0.2534 \\
Tachycardia & $9(1 \%)$ & -0.09995 & 0.7027 \\
Arrythmia & $292(10 \%)$ & 0.07249 & 0.7822 \\
Palpitations & $133(5 \%)$ & -0.1372 & 0.5994 \\
Hypertension & $636(2 \%)$ & 0.8288 & 0.0001 \\
Hypotension & $37(1 \%)$ & -0.1675 & 0.5204 \\
Myocarditis & $98(3 \%)$ & 0.4798 & 0.0513 \\
Cardiomegaly & 0 & NA & NA \\
Heart Failure & $116(4 \%)$ & 0.9417 & 0.0001 \\
Abnormal electrocardiogram & $35(95 \%)$ & -0.6378 & 0.2470 \\
Abnormal echocardiogram & $18(82 \%)$ & -0.2487 & 0.6347 \\
Death & $142(5 \%)$ & NA & NA \\
\hline
\end{tabular}

\section{Discussion}

Based on geographic location, the areas most affected by heart complications during CHIKV infection are India, portions of South America, and the Caribbean (Figure 1). Upon initial inspection, it might appear that these complications are related to the Asian lineage, due to these areas reported coinciding with Asian CHIKV circulation, especially those in South America and the Caribbean $[1,8,11,13,27]$. However, upon further exploration there was not a specific lineage connected to cardiac symptoms (Table 1).

Interestingly, there were no reports of the West African lineage causing cardiac related symptoms. This may imply that the $15-22 \%$ nucleotide difference between the West African strains and the ECSA and Asian lineages are associated with cardiac symptom abnormalities $[89,90]$. Further, due to our analysis, there is no particular lineage or mutation, such as the $\mathrm{A} 226 \mathrm{~V}$ mutation, that increases risk of heart complications during CHIKV infection. While the majority of reported cases occur around 2005 and later, which might also implicate the A226V mutation, the cases reported in the 1970s and the clustering evident in the phylogenetic trees and statistical analysis indicate that the A226V mutation is not associated with cardiac involvement $[1,2,7,10,14,15,24,25]$. This is supported by the number of reports from countries in South America and the Caribbean, where the circulating CHIKV are all derived from the Asian lineage and clustered together on the tree (Figures 2 and 3). This clade of related strains has been referred to as the Caribbean or Caribbean-American clade [11,27]. Based on reports of the CHIKV outbreaks in these areas, there is a wide range of non-synonymous mutations, none of which are found in all or the majority of cases $[1,11,27]$.

Arrythmias were a consistent symptom, as patients presented with tachycardia, the heart beating faster than the average of $60-100 \mathrm{bpm}[46,67,91,92]$. While this is not a definitive confirmation of cardiac distress, some patients received electrocardiograms, showing repolarization disturbances, poor $\mathrm{R}$ wave progression, and/or right bundle branch block $[67,71,85]$. Repolarization disturbances refers to alterations in the charging to membrane potential in the heart, $\mathrm{R}$ wave progression refers to the QRS complex, and the right bundle branch block refers to clotting $[93,94]$. Some patients received echocardiograms, showing altered left ventricular (LV) ejection fraction, hypo-contractility, and/or dilated LV cardiomyopathy $[67,68,71]$. Ejection fraction measures contractile dysfunction [95]. Interestingly, some patients presented with bradycardia, when the heart rate drops below $60 \mathrm{bpm}$ [46-48]. Some of these patients had to be taken off their medications 
for hypertension in order to prevent hypotensive crisis [47]. Death can be caused by any of these conditions, risk factors for which is older age and cardiac comorbidities such as hypertension and congestive heart failure $[29,31,43,47,70,74,86,96,97]$. Children usually do not have comorbidities; however, in one case there was an individual with a mutation of the SCN5A gene, which is linked to cardiac sinus node dysfunction [84]. This 10 year old presented with CHIKV infection and bradycardia, and later a pace maker had to be installed [84]. This finding is in line with that in adults; cardiac related comorbidities can be exacerbated by CHIKV infection.

One symptom of CHIKV infection that is found in all age groups has been myocarditis. Myocarditis refers to inflammation of heart tissue, and it can be caused by viral infection, thus becoming viral myocarditis [98]. For viral myocarditis to occur, the cardiomyocytes must be directly infected, resulting in cell death [19,98]. CHIKV has a broad tropism, and there is evidence for cardiac infection such as receptors for CHIKV on cardiomyocytes, including MXRA8 (low expression) and PBH (medium expression), as well as evidence of viral antigen in cardiac tissues [8,53,99-101]. Further, some studies indicate that depending on viral titer, the damage caused can be worse, though this was conducted in animal models and more work must be done to find if different viral strains in humans cause different titers and thus worse damage [102-104]. The damage induces the innate immune response, including the recruitment of natural killer cells (NKCs) and the release of cytokines, gamma interferon, and nitric oxide $[18,19,98]$. While NKCs and some cytokines can have a cardioprotective effect, other cytokines and players in the adaptive immune response, specifically T-lymphocytes, can cause further damage by killing more cardiomyocytes $[18,19,98]$. Following this, fibrosis begins to replace the damaged or dead cardiomyocytes $[19,98]$. Fibrotic infiltration of cardiac tissue is a keystone of another disease, dilated cardiomyopathy (DCM) $[98,105]$. DCM usually presents with left ventricular (LV) dysfunction, as it dilates and the heart wall thins causing contractility issues [106]. DCM can lead to heart failure [106]. Considering how prevalent viral myocarditis can be among all age groups during CHIKV infection, the danger of later DCM diagnosis for these patients is concerning. Additionally, viral myocarditis has other complications associated with it, including arrythmia, myocardial infarction, and sudden cardiac death [107]. In children, myocarditis is most commonly caused by viral infection [108], though reports show that many children later recover and/or only have mild symptoms [50,108]. Individuals who are infected by CHIKV should have their heart condition monitored via echocardiogram and/or electrocardiogram from time of hospital admittance and beyond for possible altered cardiac status so physicians may intercede if complications ensue.

Of patients admitted to hospitals, the mortality rate for CHIKV positive patients with severe conditions (including cardiac compromise) ranges from $26 \%$ to $48 \%$ [30,43,44,49,82]. While there are few studies that thoroughly examine the number of CHIKV patients who present with cardiac complications (including the use of echocardiograms to verify arrythmias), Castillo et al. estimates that $10 \%$ of their 32 patients exhibited heart complications [76]. If this is representative of all CHIKV infections, and of those cases $26-48 \%$ prove fatal, there is an unreported burden to the many countries where CHIKV circulates.

$\mathrm{CHIKV} \mathrm{co-circulates} \mathrm{with} \mathrm{other} \mathrm{arboviruses} \mathrm{such} \mathrm{as} \mathrm{Dengue} \mathrm{virus} \mathrm{and} \mathrm{Zika} \mathrm{virus,}$ and coinfection of these diseases can cause worsened symptoms $[2,15,109,110]$. In fact, there are reports of Dengue and Zika induced viral myocarditis, and reports that a prior arbovirus infection can be an additional risk factor for myocarditis $[15,24,25,109,110]$. Clinicians should ensure taking an accurate history of patients to mitigate any additional cardiovascular risks caused by coinfections or previous exposures.

\section{Conclusions}

There is limited or inaccurate reporting in many of the areas where CHIKV infections have surfaced, frequently due to lack of infrastructure [20,21]. It is possible that there are additional cardiac symptoms of CHIKV infection that are unknown, or additional patients that did not seek medical care due to access issues. Further, many CHIKV infections are 
self-limited and mild such that, even if viral myocarditis is present, the patient may not show overt symptoms prompting them to seek medical care [98]. All these factors present a clinical challenge. Physicians have recommended the use of electrocardiograms and/or echocardiograms on patients at risk of CHIKV infection, especially patients with risk factors such as old age and cardio-related comorbidities [81]. This would allow for detection of some of the more dangerous symptoms, such as myocarditis [107,111]. Additionally, history of CHIKV infection should be considered for patients presenting with early forms of DCM considering the connection between myocarditis and cardiomyopathies $[18,98]$. Combined, these clinical aspects of CHIKV outbreaks may be able to alleviate future ramifications on the health-care system as people acquire cardiomyopathy later in life.

In children specifically, it has been shown that myocarditis can cause death and incomplete recovery, and can require heart transplants [112]. There is no vaccine or specific treatment for CHIKV infection, though there is work ongoing in animal models [22,113]. Further, the knowledge of CHIKV infection among some health-care providers is lacking [114]. While the incidence of altered cardiac status due to CHIKV infection appears to be low, its true burden is unknown, and it is a risk for anyone with comorbidities such as hypertension. CHIKV should no longer be treated as a self-limited febrile illness; the data clearly show that CHIKV can kill.

Author Contributions: Conceptualization, E.M.T. and K.L.B.; methodology, E.M.T., V.V., H.K.H. and K.L.B.; formal analysis, E.M.T., V.V. and K.L.B.; investigation, E.M.T.; writing-original draft preparation, E.M.T. and K.L.B.; writing—review and editing, E.M.T., V.V. and K.L.B.; supervision, K.L.B. All authors have read and agreed to the published version of the manuscript.

Funding: This research received no external funding.

Institutional Review Board Statement: Not applicable.

Informed Consent Statement: Not applicable. This study utilized publicly available data.

Data Availability Statement: All data are included in the manuscript.

Conflicts of Interest: The authors declare no conflict of interest.

\section{References}

1. Zeller, H.; Van Bortel, W.; Sudre, B. Chikungunya: Its History in Africa and Asia and Its Spread to New Regions in 2013-2014 I The Journal of Infectious Diseases I Oxford Academic. Available online: https://academic.oup.com/jid/article/214/suppl_5/S436/2 632642 (accessed on 30 January 2021).

2. Barr, K.L.; Vaidhyanathan, V. Chikungunya in Infants and Children: Is Pathogenesis Increasing? Viruses 2019, 11, 294. [CrossRef] [PubMed]

3. Lum, F.-M.; Ng, L.F.P. Cellular and Molecular Mechanisms of Chikungunya Pathogenesis. Antiviral Res. 2015, 120, 165-174. [CrossRef] [PubMed]

4. Sourisseau, M.; Schilte, C.; Casartelli, N.; Trouillet, C.; Guivel-Benhassine, F.; Rudnicka, D.; Sol-Foulon, N.; Roux, K.L.; Prevost, M.-C.; Fsihi, H.; et al. Characterization of Reemerging Chikungunya Virus. PLoS Pathog. 2007, 3, e89. [CrossRef]

5. Ozden, S.; Huerre, M.; Riviere, J.-P.; Coffey, L.L.; Afonso, P.V.; Mouly, V.; de Monredon, J.; Roger, J.-C.; El Amrani, M.; Yvin, J.-L.; et al. Human Muscle Satellite Cells as Targets of Chikungunya Virus Infection. PLoS ONE 2007, 2, e527. [CrossRef] [PubMed]

6. Yactaya, S.; Staples, J.E.; Millot, V.; Cibrelus, L.; Ramon-Pardo, P. Epidemiology of Chikungunya in the Americas. Available online: https: / / www.ncbi.nlm.nih.gov/pmc/articles/PMC5137246/ (accessed on 31 January 2021).

7. Matusali, G.; Colavita, F.; Bordi, L.; Lalle, E.; Ippolito, G.; Capobianchi, M.R.; Castilletti, C. Tropism of the Chikungunya Virus. Viruses 2019, 11, 175. [CrossRef]

8. Cunha, M.S.; Costa, P.A.G.; Correa, I.A.; de Souza, M.R.M.; Calil, P.T.; da Silva, G.P.D.; Costa, S.M.; Fonseca, V.W.P.; da Costa, L.J. Chikungunya Virus: An Emergent Arbovirus to the South American Continent and a Continuous Threat to the World. Front. Microbiol. 2020, 11. [CrossRef]

9. McSweegan, E.; Weaver, S.C.; Lecuit, M.; Frieman, M.; Morrison, T.E.; Hrynkow, S. The Global Virus Network: Challenging Chikungunya. Antivir. Res. 2015, 120, 147-152. [CrossRef] [PubMed]

10. Mahendradas, P.; Avadhani, K.; Shetty, R. Chikungunya and the Eye: A Review. J. Ophthalmic Inflamm. Infect. 2013, 3, 35. [CrossRef]

11. Villero-Wolf, Y.; Mattar, S.; Puerta-González, A.; Arrieta, G.; Muskus, C.; Hoyos, R.; Pinzon, H.; Peláez-Carvajal, D. Genomic Epidemiology of Chikungunya Virus in Colombia Reveals Genetic Variability of Strains and Multiple Geographic Introductions in Outbreak, 2014. Sci. Rep. 2019, 9, 9970. [CrossRef] 
12. Xavier, J.; Giovanetti, M.; Fonseca, V.; Thézé, J.; Gräf, T.; Fabri, A.; Goes de Jesus, J.; Lima de Mendonça, M.C.; Damasceno dos Santos Rodrigues, C.; Mares-Guia, M.A.; et al. Circulation of Chikungunya Virus East/Central/South African Lineage in Rio de Janeiro, Brazil. PLoS ONE 2019, 14, e0217871. [CrossRef]

13. Rezza, G.; Weaver, S.C. PLOS Neglected Tropical Diseases: Chikungunya as a Paradigm for Emerging Viral Diseases: Evaluating Disease Impact and Hurdles to Vaccine Development. Available online: https://journals.plos.org/plosntds/article/figure?id=10 .1371/journal.pntd.0006919.g001 (accessed on 6 February 2021).

14. Bonifay, T.; Prince, C.; Neyra, C.; Demar, M.; Rousset, D.; Kallel, H.; Nacher, M.; Djossou, F.; Epelboin, L. Atypical and Severe Manifestations of Chikungunya Virus Infection in French Guiana: A Hospital-Based Study. PLoS ONE 2018, 13, e0207406. [CrossRef]

15. Alvarez, M.F.; Bolívar-Mejía, A.; Rodriguez-Morales, A.J.; Ramirez-Vallejo, E. Cardiovascular Involvement and Manifestations of Systemic Chikungunya Virus Infection: A Systematic Review. F1000Research 2017, 6. [CrossRef] [PubMed]

16. Godaert, L.; Nicolon, C.; Najioullah, F.; Kanagaratnam, L.; Césaire, R.; Dramé, M. Is Chikungunya Virus Infection an Independent Risk Factor for 2-Year Mortality in Older Afro-Caribbean Subjects? Infect. Drug Resist. 2020, 13, 2223-2228. [CrossRef] [PubMed]

17. Vairo, F.; Haider, N.; Kock, R.; Ntoumi, F.; Ippolito, G.; Zumla, A. Chikungunya: Epidemiology, Pathogenesis, Clinical Features, Management, and Prevention. Infect. Dis. Clin. N. Am. 2019, 33, 1003-1025. [CrossRef]

18. Kearney, M.; Cotton, J.; Richardson, P.; Shah, A. Viral Myocarditis and Dilated Cardiomyopathy: Mechanisms, Manifestations, and Management. Postgrad. Med. J. 2001, 77, 4-10. [CrossRef] [PubMed]

19. Schultz, J.C.; Hilliard, A.A.; Cooper, L.T.; Rihal, C.S. Diagnosis and Treatment of Viral Myocarditis. Mayo Clin. Proc. 2009, 84, 1001-1009. [CrossRef]

20. Lima Neto, A.S.; Sousa, G.S.; Nascimento, O.J.; Castro, M.C. Chikungunya-Attributable Deaths: A Neglected Outcome of a Neglected Disease. PLoS Negl. Trop. Dis. 2019, 13, e0007575. [CrossRef]

21. Frutuoso, L.C.V.; Freitas, A.R.R.; Cavalcanti, L.P.d.G.; Duarte, E.C. Estimated Mortality Rate and Leading Causes of Death among Individuals with Chikungunya in 2016 and 2017 in Brazil. Available online: https://www.scielo.br/scielo.php?script=sci_ arttext\&pid=S0037-86822020000100316 (accessed on 31 January 2021).

22. Guaraldo, L.; Wakimoto, M.D.; Ferreira, H.; Bressan, C.; Calvet, G.A.; Pinheiro, G.C.; Siqueira, A.M.; Brasil, P. Treatment of Chikungunya Musculoskeletal Disorders: A Systematic Review. Expert Rev. Anti Infect. Ther. 2018, 16, 333-344. [CrossRef] [PubMed]

23. Hatcher, E.L.; Zhdanov, S.A.; Bao, Y.; Blinkova, O.; Nawrocki, E.P.; Ostapchuck, Y.; Schäffer, A.A.; Brister, J.R. Virus Variation Resource-Improved Response to Emergent Viral Outbreaks. Nucleic Acids Res. 2017, 45, D482-D490. [CrossRef] [PubMed]

24. Obeyesekere, I.; Hermon, Y. Myocarditis and Cardiomyopathy after Arbovirus Infections (Dengue and Chikungunya Fever). Br. Heart J. 1972, 34, 821-827. [CrossRef]

25. Obeyesekere, I.; Hermon, Y. Arbovirus Heart Disease: Myocarditis and Cardiomyopathy Following Dengue and Chikungunya Fever-a Follow-up Study. Am. Heart J. 1973, 85, 186-194. [CrossRef]

26. Maiti, C.R.; Mukherjee, A.K.; Bose, B.; Saha, G.L. Myopericarditis Following Chikungunya Virus Infection. J. Indian Med. Assoc. 1978, 70, 256-258.

27. Nasci, R.S. Movement of Chikungunya Virus into the Western Hemisphere. Emerg. Infect. Dis. 2014, 20, 1394-1395. [CrossRef] [PubMed]

28. Powers, A.M.; Logue, C.H. Changing Patterns of Chikungunya Virus: Re-Emergence of a Zoonotic Arbovirus. J. Gen. Virol. 2007, 88, 2363-2377. [CrossRef] [PubMed]

29. Gauzere, B.; Bohrer, M.; Drouet, D.; Gasque, P.; Jaffar-Bandjee, M.C.; Filleul, L.; Vandroux, D. Infection à virus Chikungunya à La Réunion en 2005-2006: Formes graves émergentes de l'adulte en réanimation. Médecine Intensive Réanimation 2011, $20,211-222$.

30. Lemant, J.; Boisson, V.; Winer, A.; Thibault, L.; André, H.; Tixier, F.; Lemercier, M.; Antok, E.; Cresta, M.P.; Grivard, P.; et al. Serious Acute Chikungunya Virus Infection Requiring Intensive Care during the Reunion Island Outbreak in 2005-2006. Crit. Care Med. 2008, 36, 2536-2541. [CrossRef] [PubMed]

31. Economopoulou, A.; Dominguez, M.; Helynck, B.; Sissoko, D.; Wichmann, O.; Quenel, P.; Germonneau, P.; Quatresous, I. Atypical Chikungunya Virus Infections: Clinical Manifestations, Mortality and Risk Factors for Severe Disease during the 2005-2006 Outbreak on Réunion. Epidemiol. Infect. 2009, 137, 534-541. [CrossRef]

32. Ramful, D.; Carbonnier, M.; Pasquet, M.; Bouhmani, B.; Ghazouani, J.; Noormahomed, T.; Beullier, G.; Attali, T.; Samperiz, S.; Fourmaintraux, A.; et al. Mother-to-Child Transmission of Chikungunya Virus Infection. Pediatr. Infect. Dis. J. 2007, 26, 811-815. [CrossRef] [PubMed]

33. Ernould, S.; Walters, H.; Alessandri, J.-L.; Llanas, B.; Jaffar, M.-C.; Robin, S.; Attali, T.; Ramful, D.; Combes, J.-C. [Chikungunya in paediatrics: Epidemic of 2005-2006 in Saint-Denis, Reunion Island]. Arch. Pediatr. Organe Off. Soc. Fr. Pediatr. 2008, 15, $253-262$. [CrossRef]

34. Pellot, A.S.; Alessandri, J.L.; Robin, S.; Sampériz, S.; Attali, T.; Brayer, C.; Pasquet, M.; Jaffar-Bandjee, M.C.; Benhamou, L.S.; Tiran-Rajaofera, I.; et al. Severe forms of chikungunya virus infection in a pediatric intensive care unit on Reunion Island. Med. Trop. Rev. Corps Sante Colon. 2012, 72, 88-93.

35. Bessaud, M.; Peyrefitte, C.N.; Pastorino, B.A.M.; Tock, F.; Merle, O.; Colpart, J.-J.; Dehecq, J.-S.; Girod, R.; Jaffar-Bandjee, M.-C.; Glass, P.J.; et al. Chikungunya Virus Strains, Reunion Island Outbreak. Emerg. Infect. Dis. 2006, 12, 1604-1605. [CrossRef] 
36. Dilip, C.; Saraswathi, R.; Krishnan, P.; Azeem, A.; Raseena, A.; Ramya, J. Comparitive Evaluation of Different Systems of Medicines and the Present Scenario of Chikungunya in Kerala. Asian Pac. J. Trop. Med. 2010, 3, 443-447. [CrossRef]

37. Sam, I.C.; Kamarulzaman, A.; Ong, G.S.Y.; Veriah, R.S.; Ponnampalavanar, S.; Chan, Y.F.; AbuBakar, S. Chikungunya VirusAssociated Death in Malaysia. Trop. Biomed. 2010, 27, 343-347. [PubMed]

38. Menon, P.R.; Krishnan, C.; Sankar, J.; Gopinathan, K.M.; Mohan, G. A Child with Serious Chikungunya Virus (CHIKV) Infection Requiring Intensive Care, after an Outbreak. Indian J. Pediatr. 2010, 77, 1326-1328. [CrossRef]

39. Wimalasiri-Yapa, B.M.C.R.; Stassen, L.; Huang, X.; Hafner, L.M.; Hu, W.; Devine, G.J.; Yakob, L.; Jansen, C.C.; Faddy, H.M.; Viennet, E.; et al. Chikungunya Virus in Asia-Pacific: A Systematic Review. Emerg. Microbes Infect. 2019, 8, 70-79. [CrossRef]

40. Kumar, N.P.; Sabesan, S.; Krishnamoorthy, K.; Jambulingam, P. Detection of Chikungunya Virus in Wild Populations of Aedes Albopictus in Kerala State, India. Vector-Borne Zoonotic Dis. 2012, 12, 907-911. [CrossRef]

41. Chua, H.H.; Abdul Rashid, K.; Law, W.C.; Hamizah, A.; Chem, Y.K.; Khairul, A.H.; Chua, K.B. A Fatal Case of Chikungunya Virus Infection with Liver Involvement. Med. J. Malaysia 2010, 65, 83-84.

42. Nigam, A.; Sharma, S.; Jain, A.; Gupta, A.; Prakash, A. Vertical Transmission of Chikungunya Manifesting as Foetal Pericardial Effusion. J. Assoc. Phys. India 2016, 64, 76-79. [PubMed]

43. Crosby, L.; Perreau, C.; Madeux, B.; Cossic, J.; Armand, C.; Herrmann-Storke, C.; Najioullah, F.; Valentino, R.; Thiéry, G. Severe Manifestations of Chikungunya Virus in Critically Ill Patients during the 2013-2014 Caribbean Outbreak. Int. J. Infect. Dis. IJID Off. Publ. Int. Soc. Infect. Dis. 2016, 48, 78-80. [CrossRef]

44. Thiery, G.; Crosby, L.; Perreau, C.; Madeux, B.; Cossic, J.; Armand, C.; Herrmann-Storcke, C.; Najioullah, F.; Valentino, R. Critically Ill Patients with Chikungunya Virus Infection during the Carribean Outbreak 2013-2014. Intensive Care Med. Exp. $2015,3$. [CrossRef]

45. Evans-Gilbert, T. Chikungunya and Neonatal Immunity: Fatal Vertically Transmitted Chikungunya Infection. Am. J. Trop. Med. Hyg. 2017, 96, 913-915. [CrossRef] [PubMed]

46. Mendoza, I.; Morr, I.; Mendoza, I.; Morr, C.; Morr, C.; Meza, Y.; Marques, J.; Villalobos, I. Chikungunya myocarditis: An emerging threat to america I Journal of the American College of Cardiology. Available online: https:/ /www.jacc.org/doi/full/10.1016/s073 5-1097\%2815\%2960946-9 (accessed on 31 January 2021).

47. Morr-García, I.; Mendoza, I.; Octavio, J.A.; Villalobos, I.; Meza, Y.; Mendoza-Britto, I.; González, K.; Morr-Verenzuela, C.; Morr-Verenzuela, C.; Marques, J. PP. 02.25: Chikungunya induces persistent arterial hypotension in hypertensive patients. J. Hypertens. 2015, 33, e146. [CrossRef]

48. Gonzalez Carta Karina, A.; Mendoza_Britto Ivan, J.; Finizola, V.; Morr, I.; Torres, J.; Meza, Y.; Marquez, J.; Villalobos, I.; Vasquez, R.; Chazzim, G. Abstract 13292: Bradycardia as a Manifestation of Chikungunya Myocarditis. A New Threat to America. Circulation 2016, 134, A13292. [CrossRef]

49. Torres, J.R.; Leopoldo, C.G.; Castro, J.S.; Rodríguez, L.; Saravia, V.; Arvelaez, J.; Ríos-Fabra, A.; Longhi, M.A.; Marcano, M. Chikungunya Fever: Atypical and Lethal Cases in the Western Hemisphere: A Venezuelan Experience. IDCases 2015, 2, 6-10. [CrossRef] [PubMed]

50. Kumar, A.; Best, C.; Benskin, G. Epidemiology, Clinical and Laboratory Features and Course of Chikungunya among a Cohort of Children during the First Caribbean Epidemic. J. Trop. Pediatr. 2017, 63, 43-49. [CrossRef]

51. Gavotto, A.; Muanza, B.; Delion, F.; Dusacre, J.-A.; Amedro, P. Chikungunya Disease among Infants in French West Indies during the 2014 Outbreak. Arch. Pédiatrie 2019, 26, 259-262. [CrossRef] [PubMed]

52. Koeltz, A.; Lastere, S.; Jean-Baptiste, S. Intensive Care Admissions for Severe Chikungunya Virus Infection, French Polynesia. Emerg. Infect. Dis. 2018, 24, 794-796. [CrossRef]

53. Sharp, T.M.; Keating, M.K.; Shieh, W.-J.; Bhatnager, J. Clinical Characteristics, Histopathology, and Tissue Immunolocalization of Chikungunya Virus Antigen in Fatal Cases I Clinical Infectious Diseases I Oxford Academic. Available online: https: / /academic. oup.com/cid/advance-article/doi/10.1093/cid/ciaa837/5866622 (accessed on 31 January 2021).

54. Arocho, J.; Sarasua, A.; Irizarry, J.; Puig-Ramos, A.; Puig, G. 664: Strategic management of critically ill pediatric patien: Critical Care Medicine. Available online: https://journals.lww.com/ccmjournal/Citation/2019/01001/664_STRATEGIC_ MANAGEMENT_OF_CRITICALLY_ILL.627.aspx (accessed on 31 January 2021).

55. Freitas, A.R.R.; Donalisio, M.R.; Alarcón-Elbal, P.M. Excess Mortality and Causes Associated with Chikungunya, Puerto Rico, 2014-2015. Emerg. Infect. Dis. 2018, 24, 2352-2355. [CrossRef]

56. López, P.; De Jesús, O.; García-Justiniano, J.; Rivera-Amill, V. Novel Molecular Signatures of Chikungunya Virus in Puerto Rico. P. R. Health Sci. J. 2019, 38, 27-32.

57. Torres, J.R.; Falleiros-Arlant, L.H.; Dueñas, L.; Pleitez-Navarrete, J.; Salgado, D.M.; Castillo, J.B.-D. Congenital and Perinatal Complications of Chikungunya Fever: A Latin American Experience. Int. J. Infect. Dis. IJID Off. Publ. Int. Soc. Infect. Dis. 2016, 51, 85-88. [CrossRef]

58. van Enter, B.J.D.; Huibers, M.H.W.; van Rooij, L.; Steingrover, R.; van Hensbroek, M.B.; Voigt, R.R.; Hol, J. Perinatal Outcomes in Vertically Infected Neonates During a Chikungunya Outbreak on the Island of Curaçao. Am. J. Trop. Med. Hyg. 2018, 99, 1415-1418. [CrossRef]

59. van Ewijk, R.; Huibers, M.H.W.; Manshande, M.E.; Ecury-Goossen, G.M.; Duits, A.J.; Calis, J.C.; van Wassenaer-Leemhuis, A.G. Neurologic Sequelae of Severe Chikungunya Infection in the First 6 Months of Life: A Prospective Cohort Study 24-Months Post-Infection. BMC Infect. Dis. 2021, 21, 179. [CrossRef] 
60. Villamil-Gómez, W.; Alba-Silvera, L.; Menco-Ramos, A.; Gonzalez-Vergara, A.; Molinares-Palacios, T.; Barrios-Corrales, M.; Rodríguez-Morales, A.J. Congenital Chikungunya Virus Infection in Sincelejo, Colombia: A Case Series. J. Trop. Pediatr. 2015, 61, 386-392. [CrossRef]

61. Betancur, J.-F.; Navarro, E.P.; Bravo Bonilla, J.H.; Cortés, A.D.; Vélez, J.D.; Echeverry, A.; Suso, J.-P.; Cañas, C.A.; Tobón, G.J. Catastrophic Antiphospholipid Syndrome Triggered by Fulminant Chikungunya Infection in a Patient With Systemic Lupus Erythematosus. Arthritis Rheumatol. 2016, 68, 1044. [CrossRef]

62. Farrell, D.F.; Lupone, C.D.; Kenneson, A.; Cueva, C.; Heydari, N.; Barzallo Aguilera, J.H.; Polhemus, M.; Endy, T.P.; Stewart-Ibarra, A.M. Case Report: An Acute Chikungunya Infection and a Recent Secondary Dengue Infection in a Peripartum Case in Ecuador. Am. J. Trop. Med. Hyg. 2018, 98, 838-840. [CrossRef] [PubMed]

63. Kumar, S.; Agrawal, G.; Wazir, S.; Kumar, A.; Dubey, S.; Balde, M.; Yadav, B.S. Experience of Perinatal and Neonatal Chikungunya Virus (CHIKV) Infection in a Tertiary Care Neonatal Centre during Outbreak in North India in 2016: A Case Series. J. Trop. Pediatr. 2019, 65, 169-175. [CrossRef] [PubMed]

64. Kaur, N.; Jain, J.; Kumar, A.; Narang, M.; Zakaria, M.K.; Marcello, A.; Kumar, D.; Gaind, R.; Sunil, S. Chikungunya Outbreak in Delhi, India, 2016: Report on Coinfection Status and Comorbid Conditions in Patients. New Microbes New Infect. 2017, $20,39-42$. [CrossRef]

65. Cavalcante, J.W. Aspectos clínicos, laboratoriais e histopatológicos dos óbitos por Chikungunya, necropsiados no Ceará, 20162017. 2019. Available online: http:/ / www.repositorio.ufc.br/handle/riufc/43496 (accessed on 21 June 2021).

66. Sá, P.K.d.O.; Nunes, M.d.M.; Leite, I.R.; Campelo, M.d.G.L.d.C.; Leão, C.F.R.; Souza, J.R.d.; Castellano, L.R.; Fernandes, A.I.V. Chikungunya Virus Infection with Severe Neurologic Manifestations: Report of Four Fatal Cases. Rev. Soc. Bras. Med. Trop. 2017, 50, 265-268. [CrossRef] [PubMed]

67. Farias, L.A.B.G.; Beserra, F.L.C.N.; Fernandes, L.; Teixeira, A.A.R.; Ferragut, J.M.; Girão, E.S.; Pires Neto, R.d.J. Myocarditis Following Recent Chikungunya and Dengue Virus Coinfection: A Case Report. Arq. Bras. Cardiol. 2019, 113, 783-786. [CrossRef] [PubMed]

68. Del Castillo, J.; Alencar, G.; Nóbrega, M.; Mazzarollo, C.; Diniz, J.; Albuquerque, E.; Sena, A.; Silveira, C.; Osella, O. Echocardiographic Evaluation of Late Cardiac Issues Caused by the Chikungunya Fever. Arq. Bras. Cardiol. IMAGEM Cardiovasc. $2018,31$. [CrossRef]

69. Oliveira, R.d.M.A.B.; Barreto, F.K.d.A.; Maia, A.M.P.C.; Gomes, I.P.; Simião, A.R.; Barbosa, R.B.; Rodrigues, A.S.R.; Lopes, K.W.; Araújo, F.M.d.C.; do Vale, R.L.S.; et al. Maternal and Infant Death after Probable Vertical Transmission of Chikungunya Virus in Brazil-Case Report. BMC Infect. Dis. 2018, 18. [CrossRef]

70. Rahman, M.M.; Been Sayed, S.J.; Moniruzzaman, M.; Kabir, A.K.M.H.; Mallik, M.U.; Hasan, M.R.; Siddique, A.B.; Hossain, M.A.; Uddin, N.; Hassan, M.M.; et al. Clinical and Laboratory Characteristics of an Acute Chikungunya Outbreak in Bangladesh in 2017. Am. J. Trop. Med. Hyg. 2019, 100, 405-410. [CrossRef]

71. Colavita, F.; Vita, S.; Lalle, E.; Carletti, F.; Bordi, L.; Vincenti, D.; Pozzetto, I.; Aiuti, M.; Vairo, F.; Capobianchi, M.R.; et al. Overproduction of IL-6 and Type-I IFN in a Lethal Case of Chikungunya Virus Infection in an Elderly Man During the 2017 Italian Outbreak. Open Forum Infect. Dis. 2018, 5. [CrossRef] [PubMed]

72. Sharma, P.K.; Kumar, M.; Bhandari, N.; Kushwaha, A. Severe Sepsis and Septic Shock Associated with Chikungunya Fever in an Adolescent. J. Trop. Pediatr. 2018, 64, 557-559. [CrossRef]

73. Agarwal, A.; Gupta, S.; Yadav, A.K.; Nema, R.K.; Ansari, K.; Biswas, D. Molecular and Phylogenetic Analysis of Chikungunya Virus in Central India during 2016 and 2017 Outbreaks Reveal High Similarity with Recent New Delhi and Bangladesh Strains. Infect. Genet. Evol. J. Mol. Epidemiol. Evol. Genet. Infect. Dis. 2019, 75, 103940. [CrossRef] [PubMed]

74. Cardona-Ospina, J.A.; Jiménez-Canizales, C.E.; Vásquez-Serna, H.; Garzón-Ramírez, J.A.; Alarcón-Robayo, J.F.; Cerón-Pineda, J.A.; Rodríguez-Morales, A.J. Fatal Dengue, Chikungunya and Leptospirosis: The Importance of Assessing Co-Infections in Febrile Patients in Tropical Areas. Trop. Med. Infect. Dis. 2018, 3, 123. [CrossRef] [PubMed]

75. Athayde, C.C.d.; Nishijuka, F.A.; Queiroz, M.C.d.C.; Luna, M.M.; Figueiredo, J.L.; Albuquerque, N.M.d.; Castilho, S.C.R.d.; Castro, R.R.T. Acute Decompensated Heart Failure Due to Chikungunya Fever. Arq. Bras. Cardiol. 2020, 114, 19-22. [CrossRef] [PubMed]

76. Del Castillo, J.M.; Albuquerque, E.S.; Mazzarollo, C.; Oliveira, K.B.; Araujo, D.C.L.; Sena, A.D.M.; Alencar, M.P.C.; Brindeiro-Filho, D.F.; Silveira, C.A.M. P804 Heart Complication of Chikungunya Fever: Ecocardiographic Evaluation of Late Effects. Eur. Heart J. Cardiovasc. Imaging 2020, 21. [CrossRef]

77. Lee, V.J.; Chow, A.; Zheng, X.; Carrasco, L.R.; Cook, A.R.; Lye, D.C.; Ng, L.-C.; Leo, Y.-S. Simple Clinical and Laboratory Predictors of Chikungunya versus Dengue Infections in Adults. PLoS Negl. Trop. Dis. 2012, 6, e1786. [CrossRef]

78. Chandorkar, N.; Raj, D.; Kumar, R.; Warsi, S. Fever, Marked Tachycardia and Vesiculobullous Rash in an Infant with Chikungunya Fever. BMJ Case Rep. 2017, 2017. [CrossRef]

79. Lenglet, Y.; Barau, G.; Robillard, P.-Y.; Randrianaivo, H.; Michault, A.; Bouveret, A.; Gérardin, P.; Boumahni, B.; Touret, Y.; Kauffmann, E.; et al. Infection à Chikungunya chez la femme enceinte et risque de transmission materno-fœtale: Étude dans un contexte d'épidémie en 2005-2006 à l'île de la Réunion. J. Gynécologie Obstétrique Biol. Reprod. 2006, 35, 578-583. [CrossRef]

80. da Silva Junior, G.B.; Pinto, J.R.; Mota, R.M.S.; Pires Neto, R.d.J.; Daher, E.D.F. Risk Factors for Death among Patients with Chikungunya Virus Infection during the Outbreak in Northeast Brazil, 2016-2017. Trans. R. Soc. Trop. Med. Hyg. 2019, 113, 221-226. [CrossRef] 
81. Noronha, L.d.F.M.; Queiroz, R.B.d. Heart Changes in Elderly Chikungunya: Integration Review/Cardiac Changes in Elderly People with Chikungunya: Integrative Review I Noronha I Research Magazine: Care Is Fundamental Online. Available online: http:/ / www.seer.unirio.br/index.php/cuidadofundamental/article/view/8634 (accessed on 13 February 2021).

82. Nazneen, S.; Saha, M.; Hossain, R.; Ahsan, A.; Fatema, K.; Ahmed, F.; Saha, D.; Sultana, R. Chikungunya Viral Infection Requiring Intensive Care-Experience in a Tertiary Care Hospital in Bangladesh. BIRDEM Med. J. 2017, 8, 16. [CrossRef]

83. Simon, F.; Paule, P.; Oliver, M. Chikungunya Virus-Induced Myopericarditis: Toward an Increase of Dilated Cardiomyopathy in Countries with Epidemics? Am. J. Trop. Med. Hyg. 2008, 78, 212-213. [CrossRef]

84. Selly, J.-B.; Boumahni, B.; Edmar, A.; Jamal Bey, K.; Randrianaivo, H.; Clerici, G.; Millat, G.; Caillet, D. Cardiac sinus node dysfunction due to a new mutation of the SCN5A gene. Arch. Pediatr. Organe Off. Soc. Francaise Pediatr. 2012, $19,837-841$. [CrossRef]

85. Villamil-Gómez, W.E.; Ramirez-Vallejo, E.; Cardona-Ospina, J.A.; Silvera, L.A.; Rodríguez-Morales, A.J. Electrocardiographic Alterations in Patients with Chikungunya Fever from Sucre, Colombia: A 42-Case Series. Travel Med. Infect. Dis. 2016, 14, 510-512. [CrossRef]

86. Perti, T.; Lucero-Obusan, C.A.; Schirmer, P.L.; Winters, M.A.; Holodniy, M. Chikungunya Fever Cases Identified in the Veterans Health Administration System, 2014. PLoS Negl. Trop. Dis. 2016, 10. [CrossRef]

87. Mavalankar, D.; Shastri, P.; Bandyopadhyay, T.; Parmar, J.; Ramani, K.V. Increased Mortality Rate Associated with Chikungunya Epidemic, Ahmedabad, India. Emerg. Infect. Dis. 2008, 14, 412-415. [CrossRef] [PubMed]

88. Freitas, A.R.R.; Cavalcanti, L.; Zuben, A.P.V.; Donalisio, M.R. Excess Mortality Related to Chikungunya Epidemics in the Context of Co-Circulation of Other Arboviruses in Brazil. Available online: https://www.ncbi.nlm.nih.gov/pmc/articles/PMC5731794/ (accessed on 31 January 2021).

89. Powers, A.M.; Brault, A.C.; Tesh, R.B.; Weaver, S.C. Re-Emergence of Chikungunya and O'nyong-Nyong Viruses: Evidence for Distinct Geographical Lineages and Distant Evolutionary Relationships. J. Gen. Virol. 2000, 81, 471-479. [CrossRef] [PubMed]

90. Sam, I.-C.; Loong, S.-K.; Michael, J.C.; Chua, C.-L.; Wan Sulaiman, W.Y.; Vythilingam, I.; Chan, S.-Y.; Chiam, C.-W.; Yeong, Y.-S.; AbuBakar, S.; et al. Genotypic and Phenotypic Characterization of Chikungunya Virus of Different Genotypes from Malaysia. PLoS ONE 2012, 7, e50476. [CrossRef]

91. Al Amin, M.; Ibrahim, S.; Balkhair, A.; Al Busaidi, I.; Gaifer, Z.; Taher, H.B. Chikungunya Masquerading as Acute Rheumatism in an Omani Traveler. Oman Med. J. 2019, 34, 63-65. [CrossRef] [PubMed]

92. Rahim, M.A.; Uddin, K.N. Chikungunya: An Emerging Viral Infection with Varied Clinical Presentations in Bangladesh: Reports of Seven Cases. BMC Res. Notes 2017, 10, 410. [CrossRef] [PubMed]

93. Becker, D.E. Fundamentals of Electrocardiography Interpretation. Anesth. Prog. 2006, 53, 53-64. [CrossRef]

94. Tomoda, H.; Aoki, N. Right Bundle Branch Block in Acute Myocardial Infarction Treated by Primary Coronary Angioplasty and Stenting. Angiology 2005, 56, 131-136. [CrossRef] [PubMed]

95. Ashley, E.A.; Niebauer, J. Understanding the Echocardiogram. In Cardiology Explained; Remedica: Limassol, Cyprus, 2004.

96. Couturier, E.; Guillemin, F.; Mura, M.; Léon, L.; Virion, J.-M.; Letort, M.-J.; De Valk, H.; Simon, F.; Vaillant, V. Impaired Quality of Life after Chikungunya Virus Infection: A 2-Year Follow-up Study. Rheumatol. Oxf. Engl. 2012, 51, 1315-1322. [CrossRef]

97. Cerbino-Neto, J.; Mesquita, E.C.; Amancio, R.T.; Brasil, P.E.A.A.d. Events Preceding Death among Chikungunya Virus Infected Patients: A Systematic Review. Available online: https:/ / www.scielo.br/scielo.php?pid=S0037-86822020000100201\&script=sci_ arttext (accessed on 31 January 2021).

98. Mason, J.W. Myocarditis and Dilated Cardiomyopathy I Cardiovascular Research I Oxford Academic. Available online: https: / / academic.oup.com/cardiovascres/article/60/1/5/322628 (accessed on 30 January 2021).

99. The Human Protein Atlas Tissue Expression of MXRA8-Primary Data-The Human Protein Atlas. Available online: https: / / www.proteinatlas.org/ENSG00000162576-MXRA8/tissue/primary+data (accessed on 9 June 2021).

100. Schnierle, B.S. Cellular Attachment and Entry Factors for Chikungunya Virus. Viruses 2019, 11, 1078. [CrossRef]

101. Human Protein Atlas Tissue Expression of PHB-Primary Data-The Human Protein Atlas. Available online: https://www. proteinatlas.org/ENSG00000167085-PHB/tissue/primary+data (accessed on 9 June 2021).

102. Mallilankaraman, K.; Shedlock, D.J.; Bao, H.; Kawalekar, O.U.; Fagone, P.; Ramanathan, A.A.; Ferraro, B.; Stabenow, J.; Vijayachari, P.; Sundaram, S.G.; et al. A DNA Vaccine against Chikungunya Virus Is Protective in Mice and Induces Neutralizing Antibodies in Mice and Nonhuman Primates. PLoS Negl. Trop. Dis. 2011, 5. [CrossRef]

103. Zhang, H.-L.; Dong, H.-L.; Zhang, Y.-N.; Xu, L.-L.; Deng, C.-L.; Li, X.-F.; Li, X.-D.; Ye, H.-Q.; Yuan, Z.-M.; Qin, C.-F.; et al. Visualization of Chikungunya Virus Infection in Vitro and in Vivo. Emerg. Microbes Infect. 2019, 8, 1574-1583. [CrossRef]

104. Ngwe Tun, M.M.; Muthugala, R.; Kyaw Kyaw, A.; Shimada, S.; Morita, K.; Hayasaka, D. Pathogenetic Potential Relating to Metabolic Activity in a Mouse Model of Infection with the Chikungunya Virus East/Central/South African Genotype. Viruses 2020, 12, 169. [CrossRef]

105. Cojan-Minzat, B.O.; Zlibut, A.; Agoston-Coldea, L. Non-Ischemic Dilated Cardiomyopathy and Cardiac Fibrosis. Heart Fail. Rev. 2020. [CrossRef]

106. Schultheiss, H.-P.; Fairweather, D.; Caforio, A.L.P.; Escher, F.; Hershberger, R.E.; Lipshultz, S.E.; Liu, P.P.; Matsumori, A.; Mazzanti, A.; McMurray, J.; et al. Dilated Cardiomyopathy. Nat. Rev. Dis. Primer 2019, 5. [CrossRef] [PubMed]

107. Al-Akchar, M.; Kiel, J. Acute Myocarditis. In StatPearls; StatPearls Publishing: Treasure Island, FL, USA, 2021. 
108. Wiyatno, A.; Febrianti, E.S.Z.; Dewantari, A.K.; Myint, K.S.; Safari, D.; Idris, N.S. Characterization of Rhinovirus C from a 4-Year-Old Boy with Acute Onset Dilated Cardiomyopathy in Jakarta, Indonesia. JMM Case Rep. 2018, 5, e005139. [CrossRef]

109. Gonzalez Carta Karina, A.; Mendoza Britto Ivan, J.; Alvirez-Gonzalez Enrique, J.; Morr, I.; Meza, Y.; Finizola, V.; Gomez, C.; Misticchio, F.; Martinez, N.; Allison, T. Abstract 14717: Zika Myocarditis, Risk Factors, Prior Arbovirus Infection Brings Out the Worst. Circulation 2017, 136, A14717. [CrossRef]

110. Aletti, M.; Lecoules, S.; Kanczuga, V.; Soler, C.; Maquart, M.; Simon, F.; Leparc-Goffart, I. Transient Myocarditis Associated With Acute Zika Virus Infection. Clin. Infect. Dis. 2017, 64, 678-679. [CrossRef] [PubMed]

111. Blauwet, L.A.; Cooper, L.T. Myocarditis. Prog. Cardiovasc. Dis. 2010, 52, 274-288. [CrossRef]

112. English, R.F.; Janosky, J.E.; Ettedgui, J.A.; Webber, S.A. Outcomes for Children with Acute Myocarditis. Cardiol. Young 2004, 14, 488-493. [CrossRef]

113. Roy, C.J.; Adams, A.P.; Wang, E.; Plante, K.; Gorchakov, R.; Seymour, R.L.; Vinet-Oliphant, H.; Weaver, S.C. Chikungunya Vaccine Candidate Is Highly Attenuated and Protects Nonhuman Primates against Telemetrically Monitored Disease Following a Single Dose. J. Infect. Dis. 2014, 209, 1891-1899. [CrossRef] [PubMed]

114. Hunjul, G.N.E.; Balla, S.A. Knowledge of Chikungunya Disease among Academic Population in Private Universities, Khartoum State, Sudan-2019. Int. J. Trop. Dis. Health 2020, 41, 1-8. [CrossRef] 